Оригинални научни рад

УДК 821.163.41.09-1 Цријевић И.

Примљен: 29. јула 2020.

Прихваћен: 6. октобра 2020.

https://doi.org/10.46630/phm.13.2021.06

Константин Д. Ађанин ${ }^{1}$

Универзитет у Београду

Филолошки факултет

Катедра за српску књижевност са јужнословенским књижевностима

\title{
СЕНЕКИНА ФИЛОСОФИЈА ГНЕВА У ПОЕЗИЈИ ИЛИЈЕ ЦРИЈЕВИЋА
}

\begin{abstract}
Не изневеривши ни начела античкога наслеђа, које му је као песнику и латинисти епохе хуманизма било непресушно врело, као ни завете хришћанске традиције, којој се као свештено лице окретао, Илија Цријевић је успео да иза себе остави дело које сведочи о намери да уравнотежи ова два традицијска извора. Отишавши корак даље и од антике и од хришћанских завета, но при томе, не одступајући од њих, створивши довољно обиман корпус, а поглавито поетски, који ће нас у овоме раду занимати, а којим се да показати како опстаје линија слеђених традиција, Цријевић је само потврдио своју на другим местима очевидну поетску и уопште уметничку самобитност. Пошавши од Сенеке као узора, који ће му послужити да осведочи своју припадност развојној линији антике, Цријевић се није задржао на неоригиналним и дилетантским имитацијама, као и преузимањима од свога учитеља, већ је философску концепцију гнева, коју је тај учитељ утемељио, дубље сагледао и битно проширио, не осујетивши ни Сенекино ни сопствено дело.
\end{abstract}

Кључне речи: Сенека, поезија, гнев, философија, антика, хришћанство, хуманизам

ПОЕЗИЈА, ПОЕТСКО, ПОЕТИЧКО

Основним тежиштем свога певања, стилом и праксом као творитељима поступка, Цријевић законитости реторике претпоставља законитостима поетике, промишљајући поступак као недељиво преплетање двеју наоко супротстављених категорија (BOJOVIĆ 2003: 32). Да реторички обрти несумњиво преплављују читаво Цријевићево стваралаштво, па и прозне радове (POKRAJAC 2013: 14), те тако imitatio као један од битнијих поступака у стварању међу књижевницима епохе хуманизма

1 adjaninkonstantin@yahoo.com 
добија своје значајно место, сведочи и Цријевићев аутопоетички исказ, утемељен у песми „Fratri Francisco pro poetica“, а постојан у синтагми mel poeticum, која ваља у еквивалентском низу са једне стране да означи песника а са друге стране реторику (POKRAJAC 2013: 153). Цријевић на позорницу жанрова враћа заборављени oratio funebris; усавршивши га (BOJOVIĆ 2014: 58), постаће један у низу представника епидиктичног говорништва, „прозе која воли да се кити свим помоћним средствима реторике и да се у сјају и лепоти надмеће са поезијом“" (POKRAJAC 2013: 88). Посмртни говори, као прозне творевине, без обзира на инкорпорираност својих поетских сегмената, уистину јесу „проза на више места оплемењена поетичношћу и исказима личних осећања и искреног дивљења према блиским личностима“ (BOJOVIĆ 2014: 59). О реторици пак, са педагошког становишта, говориће као о „свеопштој науци, која је поезија у прози, и коју многи називају говорничком сржи или песничким медом“ (BOJOVIĆ 2014: 60). Развијајући свој критичко-филолошки рад на чистом латинском (цицероновском језику) као „узор elegantiae latinitatis“ (BOJOVIĆ 2014: 53), истицао је „међу гранама науке и књижевности, у оквиру реторике дакако, нарочито песништво“ (POKRAJAC 2013: 198).

\section{ПОЕТИКА КОНГРУЕНЦИЈЕ АНТИЧКО-ХРИШЋАНСКИХ ТЕНДЕНЦИЈА}

Песник хуманиста, тражећи полазишта за своје песничко дело, располаже двема философско-поетичким оријентацијама, платонизмом и аристотелизмом. Две су могућности опредељења: радикална селекција или, неретко, конкордизам (POKRAJAC 2016: 23). Позиција Илије Цријевића у светлу датих поларизација, позиција је помиритеља академског аристотелизма (оног изворног, који зенит своје превласти и обраде доживљава тек у 16. столећу) са новооткривеним платонизмом. Но, међутим, констатација Даринке Невенић-Грабовац да је Цријевић imitatio довео до нивоа парадоксалности, тако да читајући његова дела чак из вида губимо свест о било каквој имитацији (POKRAJAC 2013: 15) разложно се може проширити, те казати, да Цријевић, штавише, imitatio развија до степена потраге за својственим обрасцем (emulatio), као неко ко се није „задовољавао простим копирањем и позајмљивањем“, већ у њему самом врви од стваралачког нерва (POKRAJAC 2013: 199), а то постиже привидом перманентне скривености хришћанских елемената (БОЈОВИЋ 2014: 61). Надаље, платоновско-аристотеловску расправу о створености односно вечности света, Цријевић, мирандоловски расположен (POKRAJAC 2016: 22), а при томе као poeta teologus и poeta rhetor, не разумева само као pax philosophiae и pax fidei, промишљајући о васкрснућу ставом платоничара који промишља о постизању блаженства (BOJOVIĆ 2014: 60). 
Тако у његовом спеву De Epidauro, вишестрано важном по вредновање његовог књижевног рада уопште (BOJOVIĆ 2003: 31), мешање ових елемената најуспелије долази до изражаја. Већ сами proemium ове поеме (управо је на томе месту аутор тако означава), показује враћање дуга антици, будући да је ово дело компоновано по принципима хорацијевске поетике (Ad Pisones): „своје издање нисам спетљао на брзину и непромишљено“, јасно алудирајући на Посланицу Пизонима, Квинта Хорација Флака: „quod ille praecepit nonumque prematur in annum” (нека се одложи за девет година) (BOJOVIĆ 2003: 32). Митологизацијом односно увођењем Суђаја (Parcae tetricae), Медуза и Бога-Громовника (Tonans), али и реминисценцијама на Деукалиона и Пира, Бакха, Тартар, бога Епидауpa, божице које истражују тајне (POKRAJAC 2013: 40), али и класичним реторичким поступком помена лабудове песме и сећањем на седмокрако ушће Нила, приметне су црте античког наслеђа. Дабогме, хришћански је хуманизам осетан у божјем казивању Епидавранима о рајском насељу и вечном спасењу које ће доћи након неминовног рушења њиховог града. Овим се остварује вергилијевска идеја aura aetas, материјализована у Четвртој еклоги. Не до краја свестан у којој га је мери промишљање о хришћанству одвлачило у хришћански хуманизам, Цријевић наставља да пева и о заштитницима града Зеновију и Св. Влаху, о ефемерности животних недаћа, „нека нас не мучи све што је било смртно, пролазно... jep ће нам бити дато да уживамо живот/ и то у отаџбини небеској...“, да би се говорећи Громовнику Епидаур обратио са „служим ти увек са Христом“ (BOJOVIĆ 2003: 36). Не тражећи тему и изворе своме спевавању у античкој митологији и Библији, мада се то третирало узусом његовога доба, већ у историјској и легендарној отаџбинској прошлости (BOJOVIĆ 2003: 32), Цријевић изнова емулативно врши конфронтирање античког и хришћанског амалгама, мада се emulatio оспољава и одложеном двоструком инвокацијом Рагузи и музама,не започињући дело њоме, како је то било уобичајено у дотадашњој пракси подражавања класичним узорима.

Цријевићев oratio funebris функционише у светлу таквог дуализма (POKRAJAC 2013: 86), чије стране Цријевић успева да помири, захваљујући својој способности хармонизације паганистичких и хришћанских особина. О тој се паганизацији, узгред буди речено, може расправљати и пре стасавања песника епохе хуманизма, о чему и сам Цријевић сведочи у лаудацији „Oratio funebris in regem Mathiam“, одређујући то као „старински обичај“(POKRAJAC 2013: 306). У првоме реду, сам је чин држања погребнога слова нехришћански, epitaphios logos, атинскоме становништву познат још из времена међанских ратова (POKRAJAC 2013: 88).

Напослетку, чак се у равни номиналног, Цријевићевог посмртног говора Ивану (Џиву) Гучетићу находи апострофирање познаника 
именом Јанус. Није довољно јасно је ли то римски бог, као што нема ни довољно јасних сведочанстава о животу Ивана Гучетића, како би се дала реконструисати његова биографија (сем неколиких информација које сазнајемо из писама Анђела Полицијана). Сам почетак, који тематизује феномен људске природе, обилује укрштајем дијаметрално разнородних теоријско-философских концепција, „почев од идеалиста Питагоpe, представника западнохеленске морално-религиозе реформације, па преко истакнутог хеленског материјалиста Емпедокла,до Хрисипа, представника старе Зенонове Стое до Хераклитова материјалистичког схватања развитка света“ (POKRAJAC 2013: 93-94), уводи нас у сферу паганског мислилаштва. Говорник запада у такву апотеозу блаженопочившега да његов глас упоређује са звучношћу и пријатошћу гласа Несторовог, и даље истиче у дистиху: „честити Иван диви се необичном прагу/Олимпа и под ногама гледа звезде и облаке“ (POKRAJAC 2013: 137, 143). Овим античким рефлексијама супротставиће се христијанизација Аристотеловог учења о души, те приче о Адамовом прародитељском греху, о светој тајни причешћа, неуништивости тела, кужној змији и и бесмртном животу, „по ком се праведно и правично истичу као највиши принципи, а пороци се сузбијају и уништавају сталном бригом и дејствовањем врлине“ (POKRAJAC 2013: 95).

Лаудација ујаку, Јунију Соркочевићу, структурално је блиска, морфолошки и сентенцијално, делима Цицерона, Тита Ливија и Квинтилијана (POKRAJAC 2013: 200). Ако ли реално не сагледава чињеницу о друкчијој прошлости Рагужана (трудећи се да полатини све дубровачке породице, доводећи их у везу са становницима древног Рима) а онда им Цријевић не одузима исповедање Христа, напротив, та и таква Рагуза:

„није се укаљала никаквим додиром са суседним племенима, никад није престала да се брине о њиховом очишћењу водом свете вере. Чак је и дивља племена, рекло би се, као мајка, по дужности привијала уза се, у својем крилу покрштавала и небу давала као поново рођене“. (POKRAJAC 2013: 256)

Разложна је, у хришћанском духу, Цријевићева скепса наспрам скупа који рида за оним ко је заменио смртност за бесмртност, смрт за живот, јер остајући при томе, ожалошћени се искључиво могу манифестовати као „злобни и незахвални тумачи божанске милости и њихове cpeћ"“.

У потпуно индиферентној вези са хришћански продуховљеним одбацивањем погребнога плача, oratio fumebris угарскоме краљу Матији Корвину доноси истоветан закључак, но измењеним средством. Цријевић се пита чему јадиковке ако су укопи и вечни одласци Енеје, Мемнонија, 
Диомеда и Брута славодобитно били пропраћени (POKRAJAC 2013: 306). Оно по чему се овај oratio funebris аподиктички да третирати најуспелијим из емулативне перспективе, јесте разрешење античко-хришћанских уплива. У основи, ревалоризује се полумитолошки, хомеровски чинилац фатума, воље која стоји изнад воље богова, па и самога Зевса, пресудно одлучујућа по исходиште збивања. „Sed ab inexorabili fat oneglecti ac quod ammodo damnat" (Али нас је занемарила и на неки начин казнила неумитна судбина), каже се у тренутку правдања пред пресветлим кнезом, да би се потом поновило:,Hunc illum, inquam, nobis am repente (heu crudelissima mors et invenitabile fatum) ex oculis abstulit“ (И управо њега нам је, ево, тако изненада врло свирепа смрт, авај, и неизбежна судбина отргла с очију) (POKRAJAC 2013: 283-284).

Пренебрегавајући грчко-латински образац жанрова laudatio и vitepuratio, односно горгијско-лизијски са једне и цицероновско-квинтилијановски образац са друге стране, већма оцртан у делима Ad Herenium, De inventione и Corpus rhetorum minorum (POKRAJAC 2013: 328-329), Цријевић своју посмртну похвалу посвећује жени, Павли Џамањић, најпре стога што је „часна по пореклу, по лепоти и имању“. Emulatio је очевидан већ и оваквим избором, будући да су се лаудације, по „старинским обичајима“, о којима полемише Цријевић, држале несумњиво мушкарцима, и то у Хелади, заслужним борцима који су пали јуначком смрћу, не марећи за социјални статус, а у Риму, знаменитим патрицијима. Хришћанске особине скрушености, честитости и смерности, дају се запазити у личности Павле Џамањић, жене „која је родила петоро деце и одмалена им улевала у душу страх божански, као добра супруга и мајка непроцењиве вредности. Она пожртвовано води кућу, верује у бога, одлази на проповеди и мисе“ (POKRAJAC 2013: 338). Овај oratio funebris сагледава личност Павле Џамањић као хришћанке, у јаком контрасту наспрам мерила лепоте античке жене, катоновских назора, јер она није „узвишена Корнелија са дванаестро деце“ (POKRAJAC 2013: 341).

Ако је суштина oratio funebris-a Павли Џамањић, без сваке сумње, депаганизација моралног естетизма какав је успоставила антика, неопозиво стварајући од ње узор-хришћанку, мора се признати да песма „Празник у затвору“ доноси сасвим различит одблесак, будући да је основно расположење лирског субјекта уочи Божића несродно самом празнику и оним осећањима која тај празник ваља да побуди. Тренуцима мира које овај благдан изазива и које је изазвао Христовим рођењем, лирски субјект противставља своје тамничке околности, у толиком степену, да ће изрећи „и ето, ја сам не могу да осетим Божића срећу,/очајном, тај ми је дан тужнији него и сам/Велики петак, тај дан ко да укоп је божјега сина/ невредним сматрам да чак „рождества“ и приметим дан“ (BOJOVIĆ 2007: 361). Преиспитујући чак сопствену личност и и питајући се за грехе које 
је починио (а у тамници пребива кажњен за увреду нанесену пуници у распри са њоме и тастом који су му ускратили женин мираз, првобитно га обећавши) (KERBLER 1915: 238), он неће поћи за хришћанским грешницима или поклоницима врлине, но ће исказати „у ме не упиру прст, да сам нечасни Вер, Катилина,/ нисам ни Спартак ја роду свом, никако не!/Бруте, Трасеје ја следим, за род свој оклевао не бих/ туђу да пролијем крв, или да погинем сам“ (BOJOVIĆ 2007: 361). И неопозиво остајући у недоумици зашто се налази у затвору, пред дан који „ко да је дан укопа божјега сина“, не обраћа се Богу но античком божанству, упитавши: „тако награђујеш зар, Фебе, свог песника“ (BOJOVIĆ 2007: 361).

Нит Цријевићевог песничког израза усмерена је ка принципу одржавања нивелације између античког наслеђа, које, и када говори о љубави (у платоновској опозицији божанске и смртне, а у контексту Тимаја) преиначава са становишта хришћанског каноника, и хришћанске традиције, чије концепције страсти и пожуде, љубави стране, „поткрепљује мишљењима хеленских филозофа и римских писаца“ (POKRAJAC 2013: 13), те опаску Дивне Мрдеже Антонине да је Цријевић „radom potpomogao destruiranju monističkog srednjovekovnog mišljenja“"(MRDEŽA ANTONINA 1991: 136), не ваља дословно схватити.

\section{ТРАНСПОЗИЦИЈА СЕНЕКИЈАНСКЕ КОНЦЕПЦИЈЕ ГНЕВА}

Да Цријевић није крадљивац античких благодети и пуки имитатор, већ емулатор који ту антику своме добу предочава, на начин човека необичнога духа, пунога противречности (ŠALABALIĆ 1971: 247-268), оне противречности усклађене са, хердеровски говорећи, духом времена (KOLENDIĆ 1951: 71),примећује се и увидом у Цријевићево поимање гнева.

Спорећи се са Богом што жели да га због старости уништи, Епидаур из Цријевићевог спева De Epidauro, разметљиво казује историју свога постојања, као град који је сачувао све тековине старога и великога Рима, страхујући да му Бог не нашкоди, иако је он чувар његових светиња. Тај спор, по свим мерилима фојербаховски (POKRAJAC 2013: 34), воде, „Епидаур - паганин са својим национално ограниченим Богом“ и Бог, „паганин, којем је нација изнад човека“. Изнова претресајући атрибут Tonans (Громовник), у Цријевићевој поезији немало пута запажен („праском силних громова/проломи небо, свесилни“, „због тебе Јупитер сам, очаран, ману свој гром“, „преча но Јупитров гром тема је“, „трокраки гром Јупитров запара ноћ“, „трокраку муњу и гром Јупитру отеће та“, „доказ је Јупитер сам муње кад шаље и гром“ (ŠALABALIĆ 1971: 247, 253, $255,256,258,263)$, који Бога одређује као гневног, оног који се жести, 
али исто тако и оног за кога исход гневљења није болест него излечење и чија казна „не чини зло, већ га лечи, под видом да га чини“, запажа се Цријевићево изванредно умеће да једним атрибутом који ће упутити на античко божанство, покрене и развије причу о гневу која се назире из подтекста (SENEKA 2002: 12, 13). Дакле, излечење Епидауру Бог приказује управо у његовој будућој несрећи, која треба да донесе царство небеско, препоручујући му пасивност и неборбеност: „ти си срећан са своје будуће пропасти, и треба да желиш свој коначан пад, јер ћеш ускоро оживети и ускрснути на много лепшем месту; твојим ћу губитком већу корист искупити: кроз страшне несреће, покоље и невоље, доћи ће боља судбина“ (POKRAJAC 2013: 76). Те хришћанске особине пасивности (или боље трпељивости) и неборбености не одражава ни сам Епидаур, будући да се гневи на Бога, устајући против његове воље која жели Епидаурову привидну пропаст, некмоли епидаврански властелин, што у свима побуђује тај исти гнев, иако разуверен од Епидаура кога Бог разуверава о природи тога гнева („плану у нама тада незнани бес“). Не верујући, својим паганским срцем (POKRAJAC 2013:38) у Божје „обновићу те обнове ради“, властелин подстиче на борбу, „јер је грех надживети отаџбину“, што је у потпуности кохерентно сенекијанској визија гнева, „као жеље, а не могућности да се неко казни“, и то жеље, поглавито, најслабијих (властелина као представника Епидаврана) који се љути на најмоћније (Громовника), жеље која не би да побуди казну, којој се онај ко жели не може надати (SENEKA: 2002: 9, 21). Да гнев у себи ипак има нечег корисног, како веле перипатетичари, а Аристотел у првом реду, и да је све неосвојиво без њега и да је као такав потребан, али не као вођа већ као војник (SENEKA 2002: 16), што Сенека негира, показује функција епидавранског властелина, који у себи, гневећи се, минорно одступа од сенекијанске философије гнева, приближујући се аристотелијанској, но тај властелин ипак страда пред Божјим гневом, сенекијанским, јер је дошло до судара два поимања гнева, од којих је Сенекино поимање Цријевићу ближе. Напослетку, не примењујући доследно Сенекино учење о гневу, но га употпуњујући једном нотом sui generis гнева, Аристотелу блиском, а у позадини религијске приче, антиципације Дубровника као својеврснога Новога Јерусалима, Цријевић оправдава начело синхроницитета противречја о којем Колендић говори.

У циклусу од тринаест песама посвећених Флавији, скупине песама од прворазреднога значаја на нивоу целокупнога Цријевићева опуса (KERBLER 1915: 234), за коју се извесно може претпоставити да је Фулвија, ванбрачна кћи Јулија Помпонија Лета (која је знала српски језик колико и њен адоратор класичне језике) (RAČKI 1872: 158) сходно томе да у хуманиста анаграми нису били несвакидашња појава (KOLENDIĆ 
1951: 68)), свеучитеља академије на Квириналу коју је Цријевић похађао, примећујемо оно што Сенека назива развојем и сузбијањем осећања гнева. Не трудећи се да сав гнев излије намах на Флавију само стога што му није испрва била податна, варљиво обезвредивши обећање које је дала, лирски субјект понајпре жали за изгубљеном слободом („слободан беjax ја и уживах у безбедном миру:/оде слобода сад сва, оде њен пријатељ мир“.), немилице се канећи да схвати њено одбијање и либећи се да прихвати одсуство патње којом њена душа неће одисати чак и када он умре („нећеш ни косе да чупаш, ни ноктима лице да грдиш,/ ни да ме дозиваш све, по трећи, по четврти пут“ (ŠALABALIĆ 1971: 252, 254)). Непомирен са немањем слободе и Флавије, он ће почети да се гневи, упозоравајући је на пролазност младеначких заноса и скору старост која ће избрисати лепоту, натуралистички изменивши њену физиономију у симбол непривлачности („ако си икоме млада показала охоли презир/с двоструком каматом, знај, кад остариш, платићеш то“; „гронула, висиће кожа са образа млитавих, старих/, ћелава, бојићеш тад теме где опадне влас“ (ŠALABALIĆ 1971: 260). Спознавши бескорисност гневљења изрећи ће: „Ипак нек те поштеди (Бог), да савест не мори ти душу,/нека, испаштаћу ја уместо тебе твој грех“ (ŠALABALIĆ 1971: 268). „Највећи лек за гнев је одлагање. Не покушавај да га сузбијеш одједном: он ће бити цео побеђен ако се откида део по део“, вели Сенека на једноме месту (SENEKA 2002: 61). У раздражљиве, ако завиримо у Платонову Државу, Аристотел поред болесника и оронулих, убраја и заљубљене. Узгред, давши обећање, Флавија га крши, изазивајући тиме у субјекту који чезне гнев, подстакнут неправедно претрпљеном увредом, у чему препознајемо и присенак Лактанцијевог виђења гнева (SENEKA 2002: 62). Међутим, разапетог између сенекијанског одлагања гнева и задовољства „јер је слатко патњу враћати патњом“ (SENEKA 2002: 64), Флавијиног поклоника растрже и филодемовска лепота и оправданост узвраћене патње. У четвороструком укрштају Сенекине, Аристотелове, Лактанцијеве и Филодемове теорије гнева, уплиће се и хришћански мотив жртвовања зарад другога,тј. примања туђега греха на себе, вечити проблем богољубљења ближњега свога, чиме се и и завршава лирски наратив о љубави Флавије и њеног обожаваоца, дакако, у значењу преваге хришћанске координате.

Сенека експлицитно поучава да је гнев непријатељ човековога разума, али да се, упркос томе или можда баш управо стога, рађа тамо где се налази разум (SENEKA 2002: 10). На скоро истоветну формулацију оваквога схватања гнева, наилазимо читајућу Цријевићев oratio funebris Ивану (Џиву) Гучетићу: „Али колико пута у нама загосподари разумом укроћено оно што нам је природа усадила наопаким законима!“ (Quoties sabiugata animi rationae que nobis insita est a natura preposteris legibus in 
nobis dominantur.) (POKRAJAC 2013: 116, 131). Поставши добар ученик сенекијанске школе гнева, Цријевић надасве бива свестан да код животиња нема гнева, јер звери познају само „снагу насртаја, бесноћу, дивљину, спремност за напад“ (SENEKA 2002: 10), те то у овој лаудацији и истиче: „Постоји, међутим, стална снага живота и осећања, а уз то двострука телесна душа, од којих једну делимо с биљкама, а обе с неразумним животињама“. (Illa enim vegetandi ac sentiendi vis ac duplex corporis anima quarum alterutra plantis, utraque vero brutis animalibus communicamus (POKRAJAC 2013: 116, 131)). Понеку особину епидавранског Бога из Цријевићеве раније анализиране творевине има и представа о Богу у овоме говору, дубоко хришћански контекстуализујући казну, у оквирима сенекијанског виђења гнева, који за казном тежи (SENEKA 2002: 13).

„Сам Бог, дакле, не ствара злочине већ казне за злочине. Греси се односе на прве преступнике а казна на Бога. И тако није увек зло ако се рђаве штеточине казне, јер тиме постају боље“ (Ipse non igitur scelera deus, sed scelerum paenas creat. Scelera ad primos defectores, paena ad deum refertur. Atque ideo non semper mala est: malos puniendos calamitosos exercendo efficit meliores"(POKRAJAC 2013: 118,133).

Допуштајући перипатетичку диференцијацију различитих врста гнева као и многобројних његових именовања, а беспоговорно доказујући његову штетност (SENEKA 2002: 11, 12), насупрот перипатетичара, Сенека ће своме потоњем посредном следбенику, Цријевићу, дати простора да се запита над тим проблемом: „Ко не зна да гнев, несмотреност, дрскост, бол и страх угрожавају стрпљење, а исто тако храброст и духовну снагу" (Quis nescit iram, temeritatem, audaciam, dolorem, metum, patientiam atque fortitutudinem ac totum animi robur oppugnare? (POKRAJAC 2013: $117,132))$. Испитујућу тај и такав гнев, Цријевић га неће приписати природи, „упорни рат“, како вели, већ „кужној змији“, реализујући на фону целине овај oratio funebris у рефлексу хришћанскога кључа: „Овај упорни рат није нам, наравно, објавила сама природа као што мисли већи број људи мучећи бригама срце смртника, већ она кужна змија испуњена завишћу и злобом и смишљајући неку општу пропаст" (Quod sane pertinax bellum non natura ipsa nobis indixit, ut plaerique arbitrantur curis acuens mortalia corda, sed ille tabificus serpens livore atque invidia percitus et quodam commune meditatus exitium“ (POKRAJAC 2013: 117, 132)).

Примедба Злате Бојовић о фиксираности у многоме експлицираног набоја плутархистичких биографија поред црта самих куртоазних посмртних говора у жанру oratio funebris (BOJOVIĆ 2014: 59), који Цријевић усавршава, није случајна, будући се развојна линија античке традиције не продужава плутархистички у Цријевићеву делу само на плану пукога слеђења биографизације, пре свега, слеђењем идеје гнева из 
Плутархова дела Савладавање гнева. Присенак те књиге и Плутарховог учења о гневу можда на најбољи начин следи oratio funebris Јунију Copкочевићу, ауторовом ујаку. Свагда заступајући правичност и разумност, мудрост као мајку свих врлина, у делању је претпостављајући пороцима, Јуније Соркочевић је не само делом и речју, што ће рећи унутрашњим изгледом, неголи и спољашњим, био пример ваљанога поступања (POKRAJAC 2013: 249). „Не супротстављати пороке пороцима“, каже Сенека, призивајући из богатога хеленскога наслеђа управо Плутарха и његов exemplum о пантократору Ктезифону који је мазги узвратио ударац ногом (SENEKA 2002: 102, 103), исто као што говорећи о уздржању од гнева Сенека призива баш Плутарха, а Илија Цријевић, који поучавајући у плутархистичком маниру, поучава о гневу, призваће баш Сенеку, уз Кинеја, Симонида, Темистокла и Митридата (POKRAJAC 2013: 249). Сажимајући на тај начин све врлине Јунија Соркочевића, а истичући вајкадашње одсуство гнева у његовом животу, Илија Цријевић лик свога ујака Јунија Соркочевића непобитно темељи на тој носивости етике хришћанскога делања.

Осетивши у раној младости дах Сенекиних трагедија, њихов „узвишен тон и тмурност“ (BOJOVIĆ 2014: 51), мргодну лепоту трагедије коју ваља спуштена чела да Сенекин лик отутњи у своме плахом монологу (ŠALABALIĆ 1971: 48), Илија Цријевић је у академији Јулија Помпонија Лета и сам учествовао у извођењу античких драма под руководством Џованија Сулпича и нећака папе Сикста IV, Ријарија (KOLENDIĆ 1951: 69). Енкомијастички топос доласка божанског дечака (puer divinus) у остварењу златнога века (aura aetas), доходио је међу дубровачке петраркисте захваљујући поред Овидија и Хорација, а и Тибула, никоме другоме до Сенеки (POKRAJAC 2016: 10). До појаве Аурелија Августина и Северина Боеција извори за сазнавање Платона и платонистичких дијалога, у првоме реду јесу Цицерон и Сенека (POKRAJAC 2016: 23). Једно од омиљених алегоријских уопштавања петраркистичке метафоре песничке грађе, која се сакупља као пчелињи мед и восак или свила из свилене бубе (PANTIĆ 1963: 12), преузето је од Сенеке (POKRAJAC 2016: 95). Сенекина је улога важна и као улога непосредног хроничара егзистенције одређених жанрова у књижевности старога Рима, уз Квинтилијана и Марцијала (POKRAJAC 2016: 239). За најпревођеније писце, свакидашњу лектиру песника дубровачкога хуманизма, сматрани су Вергилије, Овидије, Плаут, поменути Марцијал и Сенека (POKRAJAC 2016: 338). Не треба даље наводити колики је значај Сенекино дело имало на пољу развоја хуманизма у Дубровнику, на Илију Цријевића, превасходно. Нема сумње да у прилог свему највише говори чињеница, која обелодањује како је Илија Цријевић, упркос Сервијевом приписивању једног 
броја песама ласцивнога садржаја Вергилију, одбацио такве тврдње, само стога, што се у 59. глави својих Центурија Анђело Полицијано позвао на Луција Анеја Сенеку, „потпуно му поверовавши иако се у то није заклео“ (POKRAJAC 2013: 184).

\section{Цитирана литература}

BOJOVIĆ 2003: 3. Бојовић, Ренесанса и барок, студије и чланци о дубровачкој књижевности, Филолошки факултет, Народна књига, Београд, 2003.

BOJOVIĆ 2007: 3. Бојовић, Книжевност Дубровника, ренесанса и барок, Филолошки факулетет, Београд, Кораци, Крагујевац, 2007.

BOJOVIĆ 2014: 3. Бојовић, Историја дубровачке књижевности, Српска књижевна задруга, Београд, 2014.

KERBLER 1915: Iz mladih dana triju humanista Dubrovčana 15. vijeka (Karlo Pavlov Pucić, Ilija Lampričin Crijević i Damjan Paskojev Benešić), Rad JAZU, 206, 1915

KOLENDIĆ 1951: П. Колендић, Крунисање Илије Цријевића у академији Помпонија Лета, Зборник радова књ. Х, Институт за проучавање књижевности САН књ. 1, Београд, 1951.

PANTIĆ 1963: М. Пантић, Поетика хуманизма и ренесансе, Просвета, Београд, 1968.

POKRAJAC 2013: Г. Покрајац, Поетика и реторика Илије Цријевића, Студије и расправе Даринке Грабоваи, Орфелин, Нови Сад, 2013

POKRAJAC 2016: Г. Покрајац, Античке рефлексије у поетиии и поезији дубровачке ренесансе, Орфелин, Нови Сад, 2016.Z̆

RAČKI 1872: Iz djela E. L. Crievića Dubrovčanina, Starine, 4, 1872.

SENEKA 2002: Lucije Anej Seneka, O gnevu, Ušće, Beograd, 2002.

ŠALABALIĆ 1971: Летопис Матице српске, књ. 407, св. 3, година 147, Нови Сад, март 1971, О Илији Цријевићу - напомена преводиоца, Aelius Lampridius Cerva - Одабране песме, написала и превела Радмила Шалабалић. 
Konstantin D. Ađanin

\section{SENNECAS PHILOSOPHIE DES ZORNS IN DER POESIE VON ILIJA CRIJEVIC}

Ohne die Prinzipe des antiken Erbes zu verlassen, die in ihm als Dichter und Latinist der humanistischen Epoche sehr hell loderten, aber auch nicht den Schwur der christlichen Tradition, der er sich als Geistlicher hinwendete, hat Ilija Crijevic es geschafft ein Werk zu hinterlassen, dass von seiner Absicht zeugt, diese beiden Quellen aus der Tradition ins Gleichgewicht zu bringen. Einen Schritt weiter gehend sowohl von der Antike als auch von dem christlichen Schwur, aber dabei nicht abweichend von ihnen hat er einen Sammlung an Werken geschaffen, vorrangig poetisch, die groß genug ist und mit welcher wir uns in dieser Arbeit außernandersetzen werden, und mit welcher gezeigt werden kann wie der Linie der gehegten Traditionen weiterbesteht. Crijevic hat seine auch andererorts leicht erkennbare poetische und künstlerische Eigenständigkeit hier nur bestätigt. Von Senneca als Vorbild, was ihm später nutzen wird um seine Zugehörigkeit zur Entwicklungslinie der Antike zu bezuegen, beginnend hat sich Crijevic niemals mit nichtoriginellen und diletantischen Nachahmungen abgefunden, als Adaptionen von seinem Lehrer, sondern hat das philosophische Konzept der Bitterkeit das sein Lehrer begründet hat, noch tiefgründiger und bedeutsam erweitert hat ohne dem Werk des Senneca oder seinem eigenenWerk zu schaden.

Schlüsselwörter: Seneca, Poesie, Zorn, Philosophie, Antike, Christentum, Humanismus 